\title{
A review of eucalypt dieback associated with bell miner habitat in south-eastern Australia
}

\author{
Grant Wardell-Johnson ${ }^{1,2}$, Christine Stone ${ }^{3}$, Harry Recher ${ }^{4}$ and A. Jasmyn J. Lynch ${ }^{1}$ \\ ${ }^{1}$ School of Natural and Rural Systems Management, The University of Queensland, Gatton, Qld 4343, Australia \\ 2Email: g.wardelljohnson@uq.edu.au \\ ${ }^{3}$ New South Wales Department of Primary Industries Science and Research, PO Box 100, Beecroft, NSW 2119, Australia \\ ${ }^{4}$ PO Box 154, Brooklyn, NSW 2083, Australia
}

Revised manuscript received 13 September 2005

\begin{abstract}
Summary
We aim to assess current knowledge, and identify gaps in knowledge concerning bell-miner-associated dieback (BMAD) in south-eastern Australia. We review BMAD as a form of forest dieback, and bell miner and psyllid interrelations. We then consider indirect and direct causal factors associated with local functional scales (tree crown), and finally, indirect and direct causal factors associated with broader functional scales (forest stand and landscape processes). This paper emphasises published literature and is a summary of a more detailed report prepared for the BMAD working group which explicitly included personal communications with many researchers, managers and members of conservation groups and the timber industry. We conclude that BMAD is a significant threat to the sustainability of the moist eucalypt forests of north-eastern NSW and south-eastern Queensland, and to biodiversity conservation at a national scale. There are serious deficiencies in the information base for most BMAD issues. While there are clear interactions between bell miners and psyllids, there are many other, less well quantified interactions that may be of greater significance to the development of the problem. We suggest that management and research efforts towards solutions urgently target disturbances that lead to changes in forest canopy structure, but there is unlikely to be a single or simple management solution. An integrated management program will be necessary as concentration on particular management regimes in isolation is unlikely to resolve the BMAD problem because BMAD is associated with interacting disturbances.
\end{abstract}

Keywords: forest management; applied research; literature reviews; dieback; herbivores; bell miner; Manorina melanophrys; psyllids

\section{Introduction}

During the early 1990s, the remnant eucalypt forests of coastal New South Wales (NSW) were increasingly recognised as suffering from canopy dieback. This dieback apparently coincided with an increase in populations of bell miners (Manorina melanophrys) in the region. This form of dieback rapidly became known as 'bell-miner-associated-dieback' (BMAD), with the acronym being used to focus research and management attention on the problem. It was soon recognised for its rapid expansion and for its severe effect on the overstorey canopy, such that whole stands of trees were killed. This led to concerns of a fundamental change in species composition, and more general effects on the biota and landscape of the region (Billyard 2004). The problem is severe, with tens of thousands of hectares in north-eastern NSW currently affected and over 2.5 million ha potentially vulnerable (Ron Billyard, NSW Department of Environment and Conservation, 2004 pers. comm.). A substantial, but undefined, area of south-eastern Queensland is similarly affected, although less attention has been directed to it. BMAD occurs on both public and private land and the area affected is expanding rapidly. The severe impact of this form of forest canopy dieback has profound implications for the conservation of the internationally significant biodiversity of the region.

This paper is a summary of a more detailed report prepared for the BMAD working group (Wardell-Johnson et al. 2005a) which explicitly included personal communications with many researchers, managers and members of conservation groups, and the timber industry. This paper emphasises the published literature, assesses the extent and relevance of existing scientific knowledge, and identifies gaps in our knowledge of BMAD.

\section{Eucalypt dieback and BMAD}

BMAD refers specifically to eucalypt forest dieback associated with the co-incidence of outbreaks of predominantly psyllid species and colonies of the bell miner or bellbird (Manorina melanophyrys). Bell miner is a honeyeater (family Meliphagidae) distributed in coastal and sub-coastal regions of south-eastern Australia. Other insect species, such as the leaf-mining microlepidopteran Acrocerops spp., observed in affected Eucalyptus saligna canopies, can also build up to damaging levels. There is a wealth of general information on these phenomena (e.g. Loyn et al. 1983; Stone 1996, 1999; Clarke and Schedvin 1999).

In BMAD areas, there is a significant correlation between bell miner density and the condition of affected eucalypt crowns (Loyn et al. 1983; Clarke and Schedvin 1999; Stone 2005, this issue). 
In these areas, the sustained presence of bell miners creates negative feedback mechanisms that maintain elevated and damaging populations of psyllids in the eucalypt canopy (Stone 1996; Ewen et al. 2003). The departure of bell miners results in a general decrease in herbivorous insect populations. However, investigations into factors associated with the commencement or facilitation of bell miner colonies, or damaging densities of psyllids, have only been preliminary (e.g. Stone 2005, this issue).

Considerable research effort is being directed at mapping canopy dieback (e.g. Coops et al. 2003, 2004; Stone et al. 2003; Stone and Coops 2004). Some literature also directly links the development of eucalypt crown decline with temporal occupation by bell miner colonies (e.g. Ewen et al. 2003). However, we have found no quantitative information on the history, distribution, spread and extent of the BMAD problem.

\section{Bell miner and psyllid inter-relations}

Bell miners are relatively restricted compared to psyllid outbreaks, that is, there are many instances of psyllid outbreaks in forests and woodlands where bell miner colonies do not occur (e.g. Campbell 1992). There are many species of psyllids (see Stone et al. 1995; Majer et al. 1997), and the groups of species associated with particular forms of forest dieback have not always been made explicit in the literature.

Bell miner colonies need tree crowns that can maintain high densities of insects and a forest structure that provides suitable nesting sites and can be defended (Loyn et al. 1983; Clarke and Heathcote 1988). There is some evidence that bell miners nest in dense understorey - habitat that can be rendered more favourable by the opening of the overstorey canopy (e.g. Smith and Robertson 1978; Pearce et al. 1995; Bower 1998). Although it is generally known that the bell miner is increasing in abundance and range in the region affected by $\mathrm{BMAD}$, there has been no quantification of this phenomenon.

Research on psyllids and bell miners has been limited to a few sites where psyllids and bell miners co-occur (e.g. Lyon et al. 1983; Stone 1996; Ewen et al. 2003). There are situations where bell miners are a major factor in facilitating and sustaining psyllid outbreaks. The limited direct evidence suggests that management practices which create stand habitats favouring the establishment of bell miner colonies are also more likely to favour psyllid outbreaks (and vice versa; Stone 2005, this issue). In such situations, colonisation by bell miners will lead to the exclusion of other avian insectivores, resulting in an increase in the numbers of psyllids and dieback of the eucalypt overstorey. However, the associated floristic and structural factors have not been quantified.

The literature has demonstrated that appropriate management can provide and maintain a diverse forest structure with the capacity to maintain bird numbers and diversity (Kavanagh and Stanton 2003). A rich avifauna will not prevent insect outbreaks, but may dampen arthropod abundances, and limit damage from herbivory (e.g. Clark 1964; Clarke and Schedvin 1999). Research on the interactions of bird assemblages and insect outbreaks has included areas affected by BMAD (e.g. Lyon et al. 1983; Clarke and Schedvin 1999).

\section{Indirect and direct factors associated with functional scale - tree crown}

\section{Insect herbivory}

The direct causes of BMAD are difficult to disentangle, and have not yet been effectively investigated. Outbreaks of some psyllid species appear to be generally associated with host tree stress (White 1971; Carnegie and Angel 2005). However, most herbivorous insects on eucalypts lay their eggs on young expanding foliage (Landsberg and Cork 1997). Therefore, environmental factors that promote young foliage provide the opportunity for herbivorous insects capable of exploiting this resource to rapidly increase their populations (e.g. Ohmart et al. 1987). Once initiated, outbreaks are likely to be associated with numerous interacting factors and feedback loops. The lack of literature on the spread of BMAD limits capacity to understand causal mechanisms, and achieve management resolution.

\section{Foliage chemistry}

Glycaspis spp. (the psyllid taxa usually associated with BMAD) are phloem feeders and obtain their essential nitrogen $(\mathrm{N})$ from free amino acids and other soluble $\mathrm{N}$ compounds. Both young expanding eucalypt foliage and epicormic (replacement) foliage have been shown to have higher free amino acid concentrations than mature adult foliage (e.g. Journet and Cochrane 1978; Marsh and Adams 1995). Also concentrations of certain free amino acids have been shown to increase in foliage on sites with high levels of soil nitrogen (e.g. Ohlson et al. 1995), although this does not appear to be a consistent response for eucalypts (Marsh and Adams 1995). On the other hand, stress-induced disruption of the carbon and water balances in eucalypts can result in accumulation of osmolyte amino acids (e.g. proline) in mature leaves (e.g. Miles et al. 1982; Marsh and Adams 1995).

\section{Foliage productivity}

Studies have also demonstrated that environmental stresses such as drought, salinity and waterlogging reduce crown evaporation rates and foliar photosynthetic efficiency in affected eucalypt crowns (e.g. Ladiges and Kelso 1977). This results in slower rates of leaf initiation and expansion, thereby providing less suitable foliage for most herbivorous insects. The impact of insect defoliation is greater on trees where the rate of leaf consumption or damage exceeds the rate of foliar replacement, and elevated populations of herbivorous insects eventually crash through lack of favourable food (e.g. Clark and Dallwitz 1975). While there has been some progress in identifying links between disturbance, soil fertility, insect herbivory and eucalypt decline in rural environments (e.g. Landsberg et al. 1990), there has been a lack of field-based or experimental research to resolve these links in native forests.

The literature demonstrates that the maintenance and expansion of psyllid outbreaks is influenced by changes in leaf phenology in a eucalypt stand (e.g. Journet 1980). Eucalypt tree crowns responding to increased penetration of sunlight into the canopy possess more vigorously developing foliage favourable to psyllids 
(Pinkard et al. 1998; Medhurst 2000). Because most psyllid species have several generations in a year (e.g. Moore 1961), they can respond quickly to an increase in leaf production brought about by increased sunlight and accelerated plant growth. However, research to explicitly address these factors in relation to BMAD has yet to be carried out.

\section{Indirect and direct factors associated with functional scale environmental disturbances and landscape processes}

A range of multi-tropic attributes (e.g. local climate/host tree condition and structure/natural enemies) has been identified as contributing to elevated psyllid populations (e.g. Clark 1964). Fragmentation, changed disturbance regimes (particularly fire and logging), and pathogens are implicated (Wardell-Johnson and Lynch 2005, this issue). Changes in nutrients and other soil constituents, climatic regimes and hydrological factors have also been implicated in BMAD and other forms of eucalypt decline associated with insects (White 1969; Landsberg 1990; Landsberg et al. 1990). There has been no attempt to unravel the various competing disturbance factors (although see Landsberg and Wylie 1991), with some literature relying on anecdotal evidence and taking an advocatory approach to the problem. We examine the extent to which the literature addresses these issues.

\section{Forest fragmentation}

Forest fragmentation, including internal fragmentation (e.g. roads and power lines), is recognised as a major biodiversity threat (e.g. Saunders et al. 1991; Laurance et al. 1998). The northeastern region of NSW is no exception (e.g. Piper and Catterall 2003), and there is some suggestion that interacting factors associated with forest fragmentation tend to favour bell miners, and hence BMAD (see Wardell-Johnson and Lynch 2005, this issue). However, there has been no quantification or testing of hypotheses associated with suggestions concerning fragmentation.

\section{Logging}

Logging and associated disturbances can have direct and indirect effects on overstorey, midstorey and understorey structure and floristics (e.g. Kanowski et al. 2003; Wardell-Johnson et al. 2005b). While there is an extensive literature on logging and the forest biota of north-eastern NSW - including environmental impact statements and management plans, which refer to particular areas, species and biotic communities, we are not aware of site-based studies in eucalypt forests which have targeted BMAD, despite logging and associated activities being carried out during the period up to and beyond the time of recognition of BMAD in the region (Flint et al. 2004). Thus studies directly associating logging, forest structure, floristics and BMAD have not been carried out. While the proliferation of dominant understorey weeds, such as lantana (Lantana camara), in northeastern NSW has been attributed largely to the disturbance caused by logging and associated activities (e.g. Wardell-Johnson et al. 2005b), no direct link between BMAD and lantana has been established.

\section{Weeds}

While lantana may not be a primary causal factor initiating BMAD, the literature suggests its presence reflects increased crown opening (Bower 1998; Wardell-Johnson et al. 2005b), which in itself may be a contributing cause for potential increases in psyllids. There has been advocacy for management strategies which reduce weed encroachment and identify and maintain ecological barriers to lantana spread (Gentle and Duggin 1997). Because large areas in the region affected by BMAD are dominated by lantana, there has also been advocacy towards the use of fire as a means of lantana control (e.g. Jurskis 2000).

\section{Soil nutrients}

The relationship between nutrients, fire and understorey structure has received some attention (e.g. Raison 1979; Adams and Attiwill 1986; Smith and Smith 1990; Ellis and Pennington 1992; Jurskis and Turner 2002). There is general agreement that the establishment of a dense shrubby understorey contributes to lowering the carbon/nitrogen $(\mathrm{C} / \mathrm{N})$ ratio, and to increased nitrogen mineralisation (e.g. Adams and Attiwill 1986). Higher concentrations of free amino acids in eucalypt foliage may occur in eucalypt stands growing in soils having relatively high soil nitrate to ammonium ratios (Adams and Atkinson 1991). Stone (2005, this issue) reports a positive correlation between bell miner density and soil ammonium content among small plots of native forest in the Richmond Range, northern NSW.

\section{Fire regimes}

There is also general agreement with a converse position that frequent low-intensity fires are associated with a grassy understorey of fire-tolerant species producing litter of higher $\mathrm{C} / \mathrm{N}$ ratios and reduced soil moisture (Raison et al. 1990; York 1999; Guinto et al. 2001). These soil conditions may provide a competitive advantage to eucalypt species that assimilate nitrogen as ammonium. However, the optimal range of inorganic $\mathrm{N}$ concentrations in the soil, and whether affected stands deviate beyond this range, has not been quantified for the species of eucalypts affected by BMAD. There is a suggestion that increasing the frequency of fire will also reduce lantana in such sites (e.g. Jurskis 2000), although this may also lead to the dominance of herbaceous weeds, particularly grasses (Gentle and Duggin 1997).

Limiting the tendency towards nitrification may provide a mechanism for facilitating the dominance by eucalypts in frequently burnt sites that are otherwise favourable to nitrophilic species (including mesic understorey species and rainforest trees — Ellis and Pennington 1989; Jurskis and Turner 2002). In establishing eucalypt plantations, any other dominant plant species present, including grasses, compete with the eucalypts (e.g. George and Brennan 2002), but even in the absence of an understorey, eucalypts can still become 'unhealthy' for many reasons independent of the processes associated with BMAD (e.g. Landsberg et al. 1990). 
For the environments in which BMAD occurs, arguments have been presented suggesting a need both for more frequent fire, and for less frequent fire in particular ecosystems (cf. Jurskis 2000 with Benson and Redpath 1997). However, the position concerning fire history is complex, and it is likely that fire regimes have in the past differed between vegetation types, locations and regions (see Henderson and Keith 2002; Wardell-Johnson et al. 2004). Recent literature, which provides anecdotal, rather than site-based survey data or experimental evidence, has not contributed to the development of fire regimes related to clear management objectives under current and likely future circumstances. Rather, an adaptive management program that includes monitoring and evaluation of various options is advocated.

Experienced field botanists in north-eastern NSW argue that there is a greater diversity of forest types in the areas affected by BMAD than warrants categorisation of forests simply into 'grassy' or 'shrubby' understorey types (J. Hunter, NSW Department of Environment and Conservation, National Parks and Wildlife Service; D. Binns, Forests NSW, 2005 pers. comm.). While high quality, quadrat-based data exist for the area, limited analysis or publication has precluded effective assessment of forest types and structures affected by BMAD. The possibility of different factors being associated with the spread of an outbreak than with its initiation may preclude clear assessment about species and vegetation types.

\section{Pathogens}

Changed hydrological balances and climatic regimes, and an increased presence of soil-borne pathogens, have all been implicated in BMAD (White 1970; Clarke and Schedvin 1999; Vertessy et al. 2001). However, the research associated with these forms of disturbance remains very scant in relation to BMAD. Recent research has demonstrated an increasingly wide geographic distribution and impact of Phytophthora spp., and has suggested that soil pathogens may be another form of disturbance relevant to BMAD (Clarke and Schedvin 1999).

\section{Management developments}

A variety of approaches to remove bell miners have been trialled on private property in north-eastern NSW in an effort to limit the spread of psyllid outbreaks and crown dieback. Examples of these approaches include, on the one hand, the clearing of understorey, removal of dead trees, conversion to grass dominated communities, grazing by cattle, and spraying to hold regrowth in check; and on the other hand, the encouragement of a dense rainforest understorey, and dam removal. Although one needs to be wary of the findings described from isolated instances, field experience in the management of BMAD may indicate some relevant research directions.

A pilot plot-based study, recently established in the Richmond Ranges, northern NSW, involved assessment of 24 plots is part of a collaborative, multi-agency research project aimed at accurately mapping the extent and severity of BMAD within a 30000 ha study area, using remotely acquired digital imagery. Stone (2005, this issue) provides an evaluation of the effects of stand structure on various environmental variables gathered at these sites. It will be appropriate to consider the relative role of floristics and structure in correlations with various BMAD related parameters at these sites. Linking plot-based research and landscape-scale processes is a fruitful research direction for BMAD (see Wardell-Johnson and Lynch 2005, this issue).

\section{Conclusion}

BMAD is a nationally significant conservation problem that has the potential to reduce the chances of achieving sustainable forest management in south-eastern Australia. There is a strong likelihood that there will be significant biodiversity loss in the medium future in the general region, including south-eastern Queensland, as well as reduced available timber volumes. Blaming bell miners for the problem and instituting management actions to remove or reduce bell miner populations will not necessarily lead to its resolution.

There are serious deficiencies in the information base for most issues concerning BMAD. While the literature has demonstrated a clear interaction between bell miners and psyllids, there are many other, less well quantified interactions that may be of greater significance to the development of the problem. To address $\mathrm{BMAD}$, it is suggested that management and research efforts be directed towards solutions that ameliorate forest structure. A pilot study using 24 plots in the Richmond Range has demonstrated one recommended research direction. A second research direction, the establishment of an adaptive management strategy associated with appropriate monitoring and evaluation is also advocated in relation to fire and introduced species management.

There is likely to be no single or simple management solution. In managing forests, it is necessary to recognise that there is a complexity of connections and interactions, many of which have yet to be deciphered. Because BMAD is associated with areas subject to interacting disturbances, concentration on particular management regimes in isolation is unlikely to resolve the BMAD problem. Rather, an integrated management program with specific objectives and experimental trials will be necessary.

\section{Acknowledgements}

We wish to thank the BMAD Working Group which funded the report from which this paper was derived, and to John Hunter, Michael Clark, Mike Calver, Brian Shearer, Jonathan Majer, Janet Farr, Rob Kooyman, Carmel Flint, Michelle (Woo Wei) Richards, Peter St Clair, Steve Rayson, Doug Binns, Bob Neil, Dailan Pugh, Penny Watson, Vic Jurskis and John Turner for information and helpful discussion. Soil samples were analysed by the Diagnostic and Analytical Services Environmental Laboratory at Wollongbar, NSW.

\section{References}

Adams, M.A. and Atkinson, P.I. (1991) Nitrogen supply and insect herbivory in eucalypts: the role of nitrogen assimilation and transport processes. In: Ryan, P.J. (ed.) Productivity in Perspective. Proceedings Third Australian Forest Soils and Nutrition Conference. Forestry Commission of NSW, Sydney, pp. 67-75.

Adams, M.A. and Attiwill, P.M. (1986) Nutrient cycling and nitrogen mineralization in eucalypt forests of south-eastern Australia. Plant and Soil 92, 341-362. 
Benson, J.S. and Redpath, P.A. (1997) The nature of pre-European native vegetation in Australia: a critique of Ryan, D.G., Ryan, J.R. and Starr, B.J. (1995) Australian Landscape: Observations of Explorers and Early Settlers. Cunninghamia 5, 285-328.

Billyard, R. (2004) BMAD Working Group perspective on forest decline and potential management solutions. In: White, T.C.R. and Jurskis, V. (eds) Fundamental Causes of Eucalypt Forest Decline and Possible Management Solutions, Proceedings of Colloquium. State Forests of NSW, Sydney, pp. 31-32.

Bower, H. (1998) For whom the bell tolls: interactions between bell miners, eucalypt dieback and bird communities in north-east NSW. Honours thesis, Southern Cross University, Lismore, 60 pp.

Campbell, K.G. (1992) The biology and population ecology of two species of Cardiaspina (Hemiptera: Psyllidae) in plague numbers on Eucalyptus grandis in New South Wales. Proceedings of the Linnean Society of New South Wales 113, 135-150.

Carnegie, A.J. and Angel, P. (2005) Creiis lituratus (Froggatt) (Hemiptera: Psyllidae) a new insect pest of Eucalyptus dunnii plantations in sub-tropical Australia. Australian Forestry 68, 59-64.

Clark, L.R. (1964) The population dynamics of Cardiaspina albitextura (Psyllidae). Australian Journal of Zoology 12, 362-380.

Clark, L.R. and Dallwitz, M.J. (1975) The life system of Cardiaspina albitextura (Psyllidae), 1950-1974. Australian Journal of Zoology 23, 523-561.

Clarke, M.F. and Heathcote, C.F. (1988) Dispersal, survivorship and demography in the co-operatively-breeding bell miner Manorina melanophrys. Ети 90, 15-23.

Clarke, M.F. and Schedvin, N. (1999) Removal of bell miners Manorina melanophrys from Eucalyptus radiata forest and its effect on avian diversity, psyllids and tree health. Biological Conservation $\mathbf{8 8}$, 111-120.

Coops, N.C., Stone, C., Culvenor, D.S., Chisholm, L.A. and Merton, R.N. (2003). Chlorophyll content in eucalypt vegetation at the leaf and canopy scales as derived from high resolution spectral data. Tree Physiology 23, 23-31.

Coops, N.C., Stone C., Culvenor, D.S. and Chisholm, L. (2004) Assessment of crown condition in eucalypt vegetation by remotely sensed optical indices. Journal of Environmental Quality 33, 956-964.

Ellis, R.C. and Pennington, P.I. (1989) Nitrification in soils of secondary vegetational successions from Eucalyptus forest and grassland to cool temperate rainforest in Tasmania. Plant and Soil 115, 59-73.

Ellis, R.C. and Pennington, P.I. (1992) Factors affecting the growth of Eucalyptus delegatensis seedlings in inhibitory forest and grassland soils. Plant and Soil 145, 93-105.

Ewen, J.G., Crozier, R.H., Cassey, P., Ward-Smith, T., Painter, J.N., Robertson, R.J., Jones, D.A. and Clarke, M.F. (2003) Facultative control of offspring sex in the cooperatively breeding bell miner, Manorina melanophrys. Behavioral Ecology 14, 157-164.

Flint, C., Pugh, D. and Beaver, D. (2004) The good, the bad and the ugly: science, process and politics in forestry reform and the implications for conservation of forest fauna in north-east New South Wales. In: Lunney, D. (ed.) Conservation of Australia's Forest Fauna, 2nd edn. Royal Zoological Society of New South Wales, Mosman, pp. 222-255.

Gentle, C.B. and Duggin, J.A. (1997) Lantana camara L. invasions in dry rainforest-open forest ecotones: the role of disturbances associated with fire and cattle grazing. Australian Journal of Ecology 22, 298-306.

George, B. and Brennan, P.D. (2002) Herbicides are more cost-effective than alternative weed control methods for increasing early growth of Eucalyptus dunnii and Eucalyptus saligna. New Forests 24, 147-163.
Guinto, D.F., Xu, Z., House, A.P.N. and Saffigna, P.G. (2001) Soil chemical properties and forest floor nutrients under repeated prescribed-burning in eucalypt forests of south-east Queensland, Australia. New Zealand Journal of Forest Science 31, 170-187.

Henderson, M.K. and Keith, D.A. (2002) Correlation of burning and grazing indicators with composition of woody understorey flora of dells in a temperate eucalypt forest. Austral Ecology 27, 121-131.

Journet, A.R.P. (1980) Intraspecific variation in food plant favourability to phytophagous insects: psyllids on Eucalyptus blakelyi M. Ecological Entomology 5, 249-261.

Journet, A.R.P. and Cochrane, P.M. (1978) Free amino acids in leaf tissue of Eucalyptus blakelyi. Phytochemistry 17, 1789-1790.

Jurskis, V. (2000) Vegetation changes since European settlement of Australia: an attempt to clear up some burning issues. Australian Forestry 63, 166-173.

Jurskis, V. and Turner, J. (2002) Eucalypt dieback in eastern Australia: a simple model. Australian Forestry 65, 87-98.

Kanowski, J., Catterall, C.P., Wardell-Johnson, G.W., Proctor, H. and Reis, T. (2003) Development of forest structure on cleared rainforest land in eastern Australia under different styles of reforestation. Forest Ecology and Management 183, 265-280.

Kavanagh, R. and Stanton, M. (2003) Bird population recovery 22 years after intensive logging near Eden, New South Wales. Ети 103, 221-231.

Ladiges, P.Y. and Kelso, A. (1977) The comparative effects of waterlogging on two populations of Eucalyptus viminalis Labill. and one population of E. ovata Labill. Australian Journal of Botany 25, 159-169.

Landsberg, J. (1990) Dieback of rural eucalypts: the effects of stress on the nutritional quality of foliage. Australian Journal of Ecology 15, 97-107.

Landsberg, J. and Cork, S.J. (1997) Herbivory: Interactions between eucalypts and the vertebrates and invertebrates that feed on them. In: Williams, J. and Woinarski, J. (eds) Eucalypt Ecology: Individuals to Ecosystems. Cambridge University Press, Cambridge, pp. 342-372.

Landsberg, J. and Wylie, F.R. (1991) A review of rural dieback in Australia. In: Growback 91. Growback Publications and Greening Australia, Melbourne, pp. 3-11.

Landsberg, J., Morse, J. and Khanna, P. (1990) Tree decline and insect dynamics in remnants of native woodlands on farms. Proceedings Ecological Society of Australia 16, 149-165.

Laurance, W.F. (1991) Edge effects in tropical forest fragments: application of a model for the design of nature reserves. Biological Conservation 57, 205-219.

Laurance, W.F., Ferreira, L.V., Rankine-de Merona, J.M. and Laurance, S.G. (1998) Rain forest fragmentation and the dynamics of Amazonian tree communities. Ecology 79, 2032-2044.

Loyn, R.H., Runnalls, R.G., Forward, G.Y. and Tyers, J. (1983) Territorial Bell miners and other birds affecting populations of insect prey. Science 221, 1411-1413.

Majer, J.D., Recher, H.F., Wellington, A.B., Woinarski, J.C.Z. and Yen, A.L. (1997) Invertebrates of eucalypt formations. In: Williams, J. and Woinarski, J. (eds) Eucalypt Ecology: Individuals to Ecosystems. Cambridge University Press, Cambridge, pp. 278-302.

Marsh, N.R. and Adams M.A. (1995) Decline of Eucalyptus tereticornis near Bairnsdale, Victoria: insect herbivory and nitrogen fractions in sap and foliage. Australian Journal of Botany 43, 39-50.

Medhurst, J. L. (2000) Growth and physiology of Eucalyptus nitens in plantations following thinning. PhD thesis, School of Plant Science, University of Tasmania, Hobart. 
Miles, P.W., Aspinall, D. and Correll, A.T. (1982) The performance of chewing insects on water stressed plants in relation to their chemical composition. Australian Journal of Zoology 10, 347-353.

Moore, K.M. (1961). Observations on some Australian forest insects. 8. The biology and occurrence of Glycaspis baileyi Moore in New South Wales. Proceedings of the Linnean Society of NSW 86(2), 185-200.

Ohlson, M., Nordin, A. and Nasholm, T. (1995) Accumulation of amino acids in forest plants in relation to ecological amplitude and nitrogen supply. Functional Ecology 9, 596-605.

Ohmart, C.P., Thomas, J.R. and Stewart, L.G. (1987) Nitrogen, leaf toughness and the population dynamics of Paropsis atomaria Olivier (Coleoptera: Chrysomelidae) - a hypothesis. Journal of the Australian Entomological Society 26, 203-207.

Pearce, J., Menkhorst, P. and Burgman, M.A. (1995) Niche overlap and competition for habitat between the helmeted honeyeater and the bell miner. Wildlife Research 22, 633-646.

Pinkard, E.A., Beadle, C.L., Davidson, N.J. and Battaglia, M. (1998) Photosynthetic responses of Eucalyptus nitens (Deane and Maiden) Maiden to green pruning. Trees 12, 119-129.

Piper, S.D. and Catterall, C.P. (2003) A particular case and a general pattern: hyperaggressive behaviour by one species may mediate avifaunal decreases in fragmented Australian forests. Oikos 101, 602-614.

Raison, R.J. (1979) Modification of the soil environment by vegetation fires, with particular reference to nitrogen transformations: a review. Plant and Soil 51, 73-108.

Raison, R.J., Keith, H. and Khanna, P.K. (1990) Effects of fire on the nutrient-supplying capacity of forest soils. In: Dyck, W.J. and Mees, C.A. (eds) Impact of Intensive Harvesting on Forest Site Productivity. New Zealand Forest Research Institute Bulletin 159, pp. 39-54.

Saunders, D.A., Hobbs, R.J. and Margules, C.R. (1991) Biological consequences of ecosystem fragmentation. Conservation Biology 5, 18-32.

Smith, A.J. and Robertson, B.I. (1978) Social organization of bell miners. Ети 78, 169-178.

Smith, P. and Smith, J. (1990) Decline of the urban koala (Phascolarctos cinereus) population in Warringah Shire, Sydney. Australian Zoology 26, 109-126.

Stone, C. (1996) The role of psyllids (Hemiptera: Psyllidae) and bell miners (Manorina melanophrys) in canopy dieback of Sydney blue gum (Eucalyptus saligna Sm.). Australian Journal of Ecology 21, 450-458.

Stone, C. (1999) Assessment and monitoring of decline and dieback of forest eucalypts in relation to ecologically sustainable forest management: a review with case study. Australian Forestry 62, $51-58$

Stone, C. (2005) Bell miner associated dieback at the tree crown scale: a multi-trophic process. Australian Forestry 68, 237-241.

Stone, C. (in press) Comparison of leaf, tree and soil properties associated with Eucalyptus saligna in a moist sclerophyll forest exhibiting canopy dieback. Austral Ecology.

Stone, C. and Coops, N.C. (2004) Assessment and monitoring of damage from insects in Australian eucalypt forests and commercial plantations. Australian Journal of Entomology 43, 283-292.
Stone, C., Spolc, D. and Urquhart, C.A. (1995) Survey of Crown Dieback in Moist Hardwood Forests in the Central and Northern Regions of NSW State Forests (Psyllid/Bell miner Research Programme). Research Paper No. 28. Research Division, State Forests of NSW, Sydney.

Stone, C., Wardlaw, T., Floyd, R., Carnegie, A., Wylie, R. and de Little, D. (2003) Harmonisation of methods for the assessment and reporting of forest health in Australia - a starting point. Australian Forestry 66, 233-246.

Taylor, G.S. (1997) Effect of plant compounds on the population dynamics of the lerp insect, Cardiaspina albitextura Taylor (Psylloidea: Spondyliaspididae) on eucalypts. In: Raman, A. (ed.) Ecology and Evolution of Plant-Feeding Insects in Natural and Man-Made Environments. International Scientific Publications, New Delhi, pp. 37-57.

Vertessy, R.A., Watson, F.G.R. and O'Sullivan, S.K. (2001) Factors determining relations between stand age and catchment water balance in mountain ash forests. Forest Ecology and Management $143,13-26$.

Wardell-Johnson, G.W. and Lynch, A.J.J. (2005) Landscape processes and eucalypt dieback associated with bell miner habitat in southeastern Australia. Australian Forestry 68, 242-250.

Wardell-Johnson, G., Calver, M., Saunders, D., Conroy, S. and Jones, B. (2004) Why the integration of demographic and site-based studies of disturbance is essential for the conservation of jarrah forest fauna. In: Lunney, D. (ed.) Conservation of Australia's Forest Fauna. Royal Zoological Society of New South Wales, Mosman, pp. 394-417.

Wardell-Johnson, G.W., Stone, C., Recher, H. and Lynch, A.J.J. (2005a) A review of eucalypt dieback associated with bell miner habitat in south-eastern Australia. Project BMAD 01/04 Science Report. University of Queensland, Gatton, Queensland. Unpublished report.

Wardell-Johnson, G.W., Kanowski, J., Catterall, C.P., McKenna, S., Piper, S. and Lamb, D. (2005b) Chapter 11. Rainforest timber plantations and the restoration of plant biodiversity in tropical and subtropical Australia. In: Erskine, P.D., Lamb, D. and Bristow, M. (eds) Reforestation in the Tropics and Sub-tropics of Australia using Rainforest Tree Species. Rural Industries Research and Development Corporation, Canberra, and the Rainforest CRC, Cairns, pp. 162-182.

White, T.C.R. (1969) An index to measure weather-induced stress of trees associated with outbreaks of psyllids in Australia. Ecology 50, 905-909.

White, T.C.R. (1970) Some aspects of the life history, host selection, dispersal, and oviposition of adult Cardiaspina densitexta (Homoptera: Psyllidae). Australian Journal of Zoology 18, 105-117.

White, T.C.R. (1971) Lerp insects (Homoptera, Psyllidae) on red gum (E. camaldulensis) in South Australia. South Australian Naturalist 46, 20-23.

York, A. (1999) Long-term effects of frequent low-intensity burning on the abundance of litter-dwelling invertebrates in coastal blackbutt forests of southeastern Australia. Journal of Insect Conservation 3, 191-199. 